\title{
A research hypothesis: Considering Traavik findings (1973-1980), during a SARS-CoV-2 pandemic.
}

\author{
Monate Mkolo ${ }^{1}$ \\ ${ }^{1}$ Sefako Makgatho Health Sciences University
}

June 24, 2020

\begin{abstract}
The pandemic has triggered worldwide social and economic disturbance, with the leading economic depression from the time when there was a Great Depression. Moreover, misleading information about the virus has spread far and wide; even some public members have raised direct questions about the possibilities of ticks to transmit the virus. These questions have not received a simple solution so far. Thus, the key idea of this paper is to provide hints and hypothesis about the publicly raised questions about the possibilities of ticks transmitting SARS-CoV-2. The approach of the mentioned questions was based on the broader perspective of using the systemic review, where this newly discovered virus (SARS-CoV-2) was put into context with respect to the once mentioned ticks coronavirus-like of Traavik et al., during the 1973-1980 period. The possibilities of ticks to transmit the virus was hypothesized. Proving or disproving this hypothesis for the emergence of SARS-CoV-2 might be possible. Therefore, the role of ticks to transmit the virus needs more attention. This could lead to more efficient measures, to block the rise of another coronavirus epidemic with persistent transmission in humans.
\end{abstract}

\section{KEYWORDS}

SARS-CoV-2, ticks, virus and hypothesis.

\section{INTRODUCTION}

On the $30^{\text {th }}$ January 2020, World Health Organization affirmed the outbreak of coronavirus disease (COVID19 ) as a health crisis of global concern and on the $11^{\text {th }}$ March 2020, as a pandemic (World Health Organization [WHO], 2020a, 2020b). The outbreak was initially detected in China, Wuhan, around December 2019 (WHO, 2020c; Huang et al., 2020). Currently, COVID-19 is a persisting pandemic, triggered by severe acute respiratory syndrome coronavirus 2 (SARS-CoV-2) (WHO, 2020d). Before we proceed, it is interesting to briefly review the current problem. As of $21^{\text {st }}$ June 2020 , more than $8,815,743$ cases of SARS-CoV-2 have been conveyed in 188 different countries, ensuing 464,895 mortalities (COVID-19 Dashboard by Center for Systems Science and Engineering [CSSE], 2020). The pandemic has triggered worldwide social and economic disturbance, with the leading economic depression from the time when there was a Great Depression (International Monetary Fund [IMF] Blog, 2020). Moreover, misleading information about the virus has spread far and wide (Clamp, 2020); even some public members have raised direct questions about the possibilities of ticks to transmit the virus (Annapolis, 2020). These questions have not received a simple solution so far. The Entomological Society of America by the U.S. Centers for Disease Control and Prevention's Division of Vector-Borne Diseases, have provided information that there is no evidence to support the fact that ticks can transmit SARS-CoV-2 (Entomological Society of America, 2020). A closer look at the literature reveals a few gaps and shortcomings. With that in mind, I raise more questions about the findings of Traavik and his colleagues, reported four decades ago, during the 1973-1980 period; can their work be considered to provide hints and hypothesis that can be tested to answer the above mentioned questions?

\subsection{Objective and scope of the paper}


The key idea is to provide hints and hypothesis concerning the publicly raised questions about the possibilities of ticks to transmit SARS-CoV-2. The provided hints and hypothesis can be tested by targeted audience mentioned below. The approach of the mentioned questions was based on the broader perspective of using the systemic review, where this newly discovered virus (SARS-COV-2) was put into context with respect to the once mentioned tick coronavirus-like of Traavik et al., during the 1973-1980 period.

\subsection{Targeted audience}

This paper is developed as a complementary and informative document for voluntary adoption by participating users, including academics, researchers, decision makers, veterinary and healthcare professionals.

\section{METHODOLOGY FOR RETRIEVAL OF THE EVIDENCE}

To provide hints and hypothesis about the possibilities of ticks to transmit SARS-CoV-2, the evidence within a systematic review was captured. The considered evidence was the $1^{\text {st }}$ January 1970 to the $1^{\text {st }}$ June 2020. Medline; Scopus; EMBASE; Google Scholar, Scifinder and the WHO Institutional Repository databases were analysed. Information sharing was achieved by using variations of the following search strategy:

Transmission: "coronavirus/ Runde coronavirus-like transmitted by ticks" or "SARS-CoV transmitted by ticks" or "SARS-CoV-2 transmitted by ticks" or "Covid-19 transmitted by ticks".

Structure: "coronavirus/ Runde coronavirus-like structure ticks" or "SARS-CoV structure ticks" or "SARSCoV-2 structure ticks" or "Covid-19 structure ticks".

Host range: "coronavirus/ Runde coronavirus-like host range ticks" or "SARS-CoV host range ticks" or "SARS-CoV-2 host range ticks" or "Covid-19 host range ticks".

Distribution: "coronavirus/ Runde coronavirus-like distribution ticks" or "SARS-CoV distribution ticks" or "SARS-CoV-2 distribution ticks" or "Covid-19 distribution ticks".

Cross-referencing was done to find extra studies meeting the inclusion criteria. The published articles were evaluated by reading the full text. The Integrated quality criteria for review of multiple study designs (ICROMS) scoring system was used to assess the standard of articles (Zingg et al., 2016). The standard of appropriate studies was ranked as 'low', 'moderate' or 'high'. The hypothesis was then formulated based on the appropriate evidence of each study.

\section{RETRIEVED EVIDENCE}

Several studies were examined, and 31 citations were found from all the databases: based on the inclusion and exclusion criteria, 8 experimental articles were found relevant for systematic review (Figure 1). The evidence from these 31 studies was identified to be of low ( 24 articles), moderate ( 1 article) and high (7 articles) standards. Eight experimental studies were specific and relevant about providing hints about the possibilities of ticks transmitting coronavirus like. The seven experimental studies were sourced from Traavik and colleagues, from the 1973s to 1978s, while one was obtained from Saikku and colleagues, reported in the 1980s (Figure 1).

Studies by Traavik and colleagues at Runde Island, Norway during the 1973s, were initiated in the attempt to solve the mystery of unusually high chick mortalities from seabird colonies reported. In the first study efforts were made in the 1973s, where a collection of Ixodes uriae samples from the seabird colonies and isolations of potential tick-borne arboviruses were conducted. During the 1975s, the second study was reported, where apart from the viruses isolates namely, Tick-borne encephalitis and Uukuniemi group viruses, additional two same strains of a coronavirus-like were found from I. uriae ticks collected during the 1973s. This latter result leads to the collection of Seabird sera samples, early May from Hernyken, RØst Island, Norway (Traavik, Meel, \& Kjeldsberg, 1977). During the 1977s, the third study was reported, where the coronavirus like strain was tentatively named Runde virus linked with Seabirds and I. uriae. The virus was termed Runde virus after the island name where the seabird colonies were situated (Traavik, Meel, \& Kjeldsberg, 1977; Traavik \& Brunvold, 1978). Several more landmark studies (Traavik, 1977; Traavik \& Brunvold, 
1978; Traavik, 1978,1979) were conducted and reported in the 1977s and 1978s in the attempt to back up the evidence of Traavik, Meel and Kjeldsberg (1977). Evidence from the cohort study indicated that the isolation of a coronavirus like agent transmitted transstadially and sustained for six months in I. uriae, was thought-provoking (Saikku, Main, Ulmanen, \& Brummer-Korvenkontio, 1980). There evidence is available, however Saikku, Main, Ulmanen and Brummer-Korvenkontio (1980), work does not overwhelmingly support the findings of Traavik, Meel and Kjeldsberg (1977); due to the lack of resources (for example, RT-PCR, RT-qPCR molecular analysis and metagenomic sequencing) four decades ago. Nonetheless, the ecological conditions of the isolations designated a coronavirus circulating among the $I$. uriae and its seabird hosts.

\subsection{Significance of the previous research by Traavik and colleagues}

The previous prospective research by Traavik and colleagues has made innovative contributions in several areas, especially in Acarology, Ecology and Virology. The knowledge about the coronavirus circulating among the I. uriae and its seabird hosts provide a hint about the possibilities of ticks to harbour and transmit coronavirus. Although, their results cannot be claimed to universally be the case for all different kinds of tick species and coronavirus. It is hard to comprehend why this knowledge should be excluded from the raised questions about the possibilities of any tick species be able to harbour and circulate coronavirus like SARC-CoV-2. Thus, the information is vital since there is ample of evidence about the different kinds of tick species that share ecological niches with potential vertebrate reservoir, such as bats, seabirds and pangolins (Olival et al., 2017; Fagre \& Kading, 2019; Málková et al., 1985; Dietrich, Go’mez-D1 'az, \& McCoy, 2010; Ramos et al., 2001; Gao et al., 2020; Khatri-Chhetri et al., 2016; Mohapatra, Panda, Nair, \& Acharjyo, 2016; Robinson, 1983).

Classification of ticks is well done in pangolins consisting of eight genera and twenty species of ticks described from six species of pangolins namely, Manis pentadactyla, M. javanica, M.crassicaudata, M. gigantea, M. tricuspis and M. temminckii. The most intriguing finding is that unassigned ticks that were described from M. tetradactyla by Robinson (1983).Amblyomma, Rhipicephalus and Aponomma genera of ticks have been described from the above mentioned Asian and African pangolin species. Asian pangolins namely, $M$. pentadactyla, M. javanica and M. crassicaudata have been associated withAmblyomma javanense. While, African pangolins namely, M. temminckii, M. tricuspis and M. gigantean have been associated with Amblyomma compressum (Sanyal, De, Rao, \& Acharjyo, 1987; Parola et al., 2003; Mohapatra, Panda, Nair, \& Acharjyo, 2016). Possible geographic distribution of hard ticks linked with pangolins is provided in figure 2. The geographic distribution was developed from different research work of Hassan, Sulaiman and Lian (2013), Kollars and Sithiprasasna (2000), Parola et al. (2003), Li, Lin, Lan, Pei and Su (2011), Mediannikov et al. (2012) and Njiokou et al. (2006).

Different reviews of the literature undertaken by Nuttall (1984) and Chastel (1980), reported that seabird ticks harbour approximately 60 viruses or variants. Evidence about viraemic transmission to seabirds has been provided by Nunn et al. (2006). Moreover, Dietrich et al. (2010), reported that hard ticks prefer to infest seabird colonies in higher latitudes. The main example is $I$. uriae, which is the most significant species when focusing on its host species assortment and geographical distribution (Pettersson et al., 2020). Possible geographic distribution of hard ticks linked with seabirds is provided in figure 3. The geographic distribution was developed from the research work of Dietrich et al. (2010).

Several landmark studies observed associate phylogenetically viruses in bats with various arboviruses which can be transmitted by ticks (Fagre \& Kading, 2019). Isolation results are providing evidence of bats being responsible for viruses isolated from either soft ticks or hard ticks. For instance, a study of Málková et al. (1985), provides evidence, whereOrnithodoros tadaridae ticks obtained from a palm tree colonized by Cuban bats were found to be infected with Estero real virus. Recently, different kinds of Ixodes species (i.e. Ixodes ariadnae, I. simplex and I. vespertilionis ) andDermacentor reticulatus have been associated with bats (Sándor et al., 2019). Possible geographic distribution of hard ticks linked with bats is provided in figure 4. The geographic distribution was developed from different research work of Zahn and Rupp (2004), Hornok et al. (2014) and Hornok et al. (2016). 


\subsection{Implications for human health}

In the light of reported evidence by Traavik and Brunvold, (1978), where the isolated Runde coronavirus agent from virus families that have RNA genomes, it is conceivable that this RNA virus may have "proofreading" systems deficiency than DNA viruses, and therefore it may be more inclined to develop and maintain genome mutations (Graepel et al., 2017). Thus, it would be reasonable to assume that this RNA virus is more likely to emerge, and for it to be capable to replicate in the cytoplasm is the best speculator of cross-species transmission from animals (for example, the above mentioned seabirds, bats and pangolins) to humans (Pulliam \& Dushoff, 2009). Therefore, it is critical to consider this assumption since, bat ticks can also bite humans and they are capable to transmit viruses between bats and human (Socolovschi, Kernif, Raoult \& Parola, 2012; Jaenson et al., 1994). The epidemiological importance for the transmission of diseases to humans from bats and bat associated ticks has become a major concern, although limited by lack of detailed information about bat ticks pathogen association and distribution (Loftis et al. 2005). However, growing urbanisation and bats adaptation to urban habitats has raised the chances for contact between domestic animals and humans with bat associated ticks and bats (Hornok et al., 2016; Krauel \& LeBuhn, 2016). Moreover, Guglielmone et al. (2014) reported ten different types of tick species feeding on pangolins also feeding on unlikely animal hosts. Some of the pangolin's ticks have been reported to bite humans (Estrada-Pena \& Jongejan, 1999; Parola et al., 2013; Durden, Merker, \& Beati, 2008; Burridge, 2001; Audy, Nadchatram, \& Lim, 1960). Limited reports of seabird tick bites to humans have been recognized (Gylfe et al., 1999; Duneau et al., 2008; Dietrich et al., 2010).

However, the fact that there are few reported cases of tick bites (ticks associated with seabird, bat and pangolin); it does not suggest that tick bites to humans do not occur. This can be due to unreported cases and undeveloped illness by the bitten person. Besides, areas where seabird, bat and pangolin ticks co-occur with other tick species that are significant vectors of animal and human pathogens signify likely contact areas for pathogen transmission. Anthroponotic factors related to the modern lifestyle can facilitate the emerging of tick-borne viruses. Today, we persistently recognize and obliged to deal with new cases of emerging viruses including tick-borne viral diseases (e.g. Wang et al. (2019), reported a new segmented virus associated with human febrile illness and ticks in China). Moreover, due to anthroponotic factors, it is not surprising that the outbreak of SARS-CoV-2 has been tentatively related with a seafood market in Wuhan, China, where the trading of wild animals may be the cause of zoonotic infection (Lu et al., 2020; Cohen, 2020). This assumption can be true since different kinds of mammalian species were purchase before SARS-CoV-2 outbreak at the Huanan seafood market as mentioned by Cohen (2020). Malayan pangolins (Manis javanica) smuggled into Southern China, are the only mammals except for Rhinolophus affinis bat (sampled from Yunnan in the year 2013) recognized to be affected by a SARS-CoV-2 related coronavirus (Lam et al., 2020; Zhou et al., 2020). This current finding by Lam et al. (2020), cannot be ignored, since the sampled pangolins independently acquired SARS-CoV-2 related viruses from bats or different animal host. However, their position as intermediate host in the development of human SARS-CoV-2 is still unclear. There is a clear dearth of consensus among researchers about the occurrence of coronaviruses, together with those associated to SARS-CoV-2, in different kinds of wild mammals found in Asia (Wang et al., 2005; Liu, Chen, \& Chen, 2019; Wang et al., 2017). These are the most relevant findings and perhaps also the most significant, since, different tick species can be associated with both mammals (bats and pangolins), and they may also harbour coronavirus as proven by Traavik, Meel and Kjeldsberg (1977), Traavik and Mehl (1975) and Saikku et al., 1980.

All these above-mentioned findings are thought-provoking, and it could be hypothesized that ticks may possibly transmit SARS-CoV-2 to humans via different ways.

\subsection{Possible hypothesis}

The hypothesis was substantial enough necessitating a full descriptive cycle diagram. Therefore, figure 5 provides a hypothesis about the possible ways that $I$. uriae ticks can use to transmit SARS-CoV-2 to humans. In relation to the evolution of host specificity and local adaptation of ticks (Klompen, Black, Keirans, \& Oliver, 1996), permits us to form the described potential hypothesis that remains to be scientifically proven. 


\section{FINAL REMARKS}

The possibilities of ticks to transmit the virus was hypothesized. Proving or disproving this hypothesis for the emergence of SARS-CoV-2 might be possible. Since, such viruses may be asymptomatic in their hosts, but the balance may be tipped over, and overt disease or behavioural aberrations may occur due to ecosystem and climate alterations. In some instances, such viruses may cross a species barrier and affect other tick species, wildlife species, domestic animals and humans. Nonetheless, isolation of coronavirus-like from a range of animals, including ticks may possibly assist to clarify the steps to emergence in humans. Therefore, the role of ticks to transmit the virus needs more attention. These could lead to more efficient measures to block the rise of another coronavirus epidemic with persistent transmission in humans.

\section{ACKNOWLEDGEMENTS}

I would like to thank Prof. Obi C.L. (Dean) and the research department from Sefako Makgatho Health Science University for their encouragement during this trying time.

\section{CONFLICT OF INTEREST}

No conflict of interest to be declared by the author.

\section{AUTHORS CONTRIBUTION}

Mkolo N.M. prepared wrote and revised the manuscript.

\section{ETHICAL STATEMENT}

Not applicable.

\section{DATA AVAILABILITY}

Data sharing not applicable to this review as no datasets were produced or analysed for this study.

\section{REFERENCE}

Audy, J.R., Nadchatram, M., \& Lim, B.L. (1960). Malaysian parasites. XLIX. Host distribution of Malayan ticks (Ixodoidea).Studies from the Institute for Medical Research, Federated Malay States,29:225-246. Retrieved May 2, 2020, from https://www.cabdirect.org/cabdirect/abstract/19612900986

Annapolis, M.D. (2020). Mosquitoes and Ticks Do Not Transmit Coronavirus. Entomological Society of America , Retrieved May 2, 2020, from https://www.entsoc.org/mosquitoes-and-ticks-do-not-transmitcoronavirus

Burridge, M.J. (2001). Ticks (Acari: Ixodidae) spread by the international trade in reptiles and their potential roles in dissemination of diseases. Bulletin of entomological research , 91 (1), 3-23. doi: https://doi.org/10.1079/BER200071

Clamp, R. (2020). Coronavirus and the Black Death: spread of misinformation and xenophobia shows we haven't learned from our past. The Conversation, Retrieved May 26, 2020, from https://theconversation.com/coronavirus-and-the-black-death-spread-of-misinformation-and-xenophobiashows-we-havent-learned-from-our-past-132802

Cohen, J. (2020). Mining coronavirus genomes for clues to the outbreak's origins. Science, Retrieved June 5, 2020, from https://www.sciencemag.org/news/2020/01/mining-coronavirus-genomes-cluesoutbreak-sorigins.

COVID-19 Dashboard by Center for Systems Science and Engineering, (2020). Dashboard by the Center for Systems Science and Engineering (CSSE) at Johns Hopkins University (JHU). ArcGIS. Johns Hopkins University , Retrieved May 21, 2020, from https://gisanddata.maps.arcgis.com/apps/opsdashboard/index.html\#/bda7594740fd40299423467b48e9ecf6 
Chastel, C. (1980). Arbovirus transmis par des tiques et associés a des oiseaux de mer; une revue générale [Tick-borne arboviruses associated with marine birds; a general review (author's transl)]. Medecine tropicale: revue du Corps de sante colonial , 40 (5), 535-548. Retrieved May 21, 2020, from https://pubmed.ncbi.nlm.nih.gov/7442512/

Dietrich, M., Gómez-Díaz, E., \& McCoy, K.D. (2011). Worldwide distribution and diversity of seabird ticks: implications for the ecology and epidemiology of tick-borne pathogens. Vector borne and zoonotic diseases (Larchmont, N.Y.) , 11 (5), 453-470. https://doi.org/10.1089/vbz.2010.0009

Doucleef, M. (2012). Scientists go deep on genes of SARS-like virus.Associated Press, Retrieved May 3, 2020, from https://www.npr.org/sections/health-shots/2012/09/25/161770135/scientists-go-deep-on-genesof-sars-like-virus

Duneau, D., Boulinier, T., Gómez-Díaz, E., Petersen, A., Tveraa, T., Barrett, R. T., \& McCoy, K.D. (2008). Prevalence and diversity of Lyme borreliosis bacteria in marine birds. Infection, genetics and evolution, 8 (3), 352-359. https://doi.org/10.1016/j.meegid.2008.02.006

Durden, L.A., Merker, S., \& Beati, L. (2008). The tick fauna of Sulawesi, Indonesia (Acari: Ixodoidea: Argasidae and Ixodidae). Experimental and applied acarology, 45 , 85-110. https://doi.org/10.1007/s10493008-9144-z.

Entomological Society of America, (2020). Mosquitoes and ticks do not transmit Coronavirus. Entomological society of America, Retrieved May 2, 2020, from https://www.entsoc.org/mosquitoes-and-ticks-do-nottransmit-coronavirus

Estrada-Peña, A., \& Jongejan, F. (1999). Ticks feeding on humans: a review of records on human biting Ixodoidea with special reference to pathogen transmission. Experimental and applied acarology , 23 (9), 685-715. https://doi.org/10.1023/a:1006241108739

Falco, M. (2012). New SARS-like virus poses medical mystery. CNN Health, Retrieved May 2, 2020, from https://thechart.blogs.cnn.com/2012/09/24/new-sars-like-virus-poses-medical-mystery/

Fagre, A.C., \& Kading, R.C. (2019). Can Bats serve as reservoirs for Arboviruses? Viruses , 11 (3), 215. https://doi.org/10.3390/v11030215

Gao, W.H., Lin, X.D., Chen, Y.M., Xie, C.G., Tan, Z.Z., Zhou, J.J., .. Zhang, Y.Z. (2020). Newly identified viral genomes in pangolins with fatal disease. Virus evolution, 6 (1), veaa020. https://doi.org/10.1093/ve/veaa020

Graepel, K.W., Lu, X., Case, J.B., Sexton, N.R., Smith, E.C., \& Denison, M.R. (2017). Proofreading-deficient Coronaviruses adapt for increased fitness over long-term passage without reversion of exoribonucleaseinactivating mutations. mBio , 8 (6), e01503-17. https://doi.org/10.1128/mBio.01503-17

Guglielmone, A.A., Robbins R.G., Apanaskevich, D.A., Petney, T.N., Estrada-Pena, A., Horak, I.G. (2014). The hard ticks of the world (Acari: Ixodida: Ixodidae) New York: Springer, Dordrecht Heidelberg, Retrieved May 9, 2020, from https://www.springer.com/gp/book/9789400774964

Gylfe, Olsen, B., Strasevicius, D., Marti Ras, N., Weihe, P., Noppa, L., ... Bergström, S. (1999). Isolation of Lyme disease Borrelia from puffins (Fratercula arctica) and seabird ticks (Ixodes uriae) on the Faeroe Islands. Journal of clinical microbiology , 37 (4), 890-896. Retrieved May 29, 2020, from https://www.ncbi.nlm.nih.gov/pmc/articles/PMC84640/

Hassan, M., Sulaiman, M.H., \& Lian, C.J. (2013). The prevalence and intensity of Amblyomma javanense infestation on Malayan pangolins (Manis javanica Desmarest) from Peninsular Malaysia. Acta tropica, 126 (2), 142-145. https://doi.org/10.1016/j.actatropica.2013.02.001. 
Hornok, S., Kováts, D., Angyal, D., Dányi, L., Kovács, R., \& Kontschán, J. (2016). Description of the male and the larva of Ixodes ariadnae Hornok, 2014. Ticks and tick-borne diseases , 7 (6), 1252-1255. https://doi.org/10.1016/j.ttbdis.2016.07.005

Hornok, S., Kontschán, J., Kováts, D., Kovács, R., Angyal, D., Görföl, T., .. Mihalca, A. D. (2014). Bat ticks revisited: Ixodes ariadnae sp. nov. and allopatric genotypes of I. vespertilionisin caves of Hungary. Parasites and vectors , 7 , 202. https://doi.org/10.1186/1756-3305-7-202

Hornok, S., Szôke, K., Kováts, D., Estók, P., Görföl, T., Boldogh, S.A., .. Sándor, A. D. (2016). DNA of piroplasms of ruminants and dogs in Ixodid bat ticks. PloS one, 11 (12), e0167735. https://doi.org/10.1371/journal.pone.0167735

Huang, C., Wang, Y., Li, X., Ren, L., Zhao, J., Hu, Y., . . Cao, B. (2020). Clinical features of patients infected with 2019 novel coronavirus in Wuhan, China. Lancet, 395 (10223), 497-506. https://doi.org/10.1016/S01406736(20)30183-5

International Monetary Fund (IMF) Blog, (2020). The Great Lockdown: Worst Economic Downturn Since the Great Depression, Retrieved May 23, 2020, from https://blogs.imf.org/2020/04/14/the-great-lockdownworst-economic-downturn-since-the-great-depression/

Jaenson, T. G., Tälleklint, L., Lundqvist, L., Olsen, B., Chirico, J., \& Mejlon, H. (1994). Geographical distribution, host associations, and vector roles of ticks (Acari: Ixodidae, Argasidae) in Sweden. Journal of medical entomology , 31 (2), 240-256. https://doi.org/10.1093/jmedent/31.2.240

Khatri-Chhetri, R., Wang, H. C., Chen, C. C., Shih, H. C., Liao, H. C., Sun, C. M., .. Pei, K. J. (2016). Surveillance of ticks and associated pathogens in free-ranging Formosan pangolins (Manis pentadactyla pentadactyla ). Ticks and tick-borne diseases , 7 (6), 12381-244. https://doi.org/10.1016/j.ttbdis.2016.07.007

Krauel, J. J., \& LeBuhn, G. (2016). Patterns of Bat distribution and foraging Activity in a highly urbanized temperate environment. PloS one, 11 (12), e0168927. https://doi.org/10.1371/journal.pone.0168927

Klompen, J.S., Black, W.C., Keirans, J.E., \& Oliver, JH.Jr. (1996). Evolution of ticks. Annual review of entomology, 41 , 141-161. https://doi.org/10.1146/annurev.en.41.010196.001041.

Kollars, T. M., Jr, \& Sithiprasasna, R. (2000). New host and distribution record of Amblyomma javanense (Acari: Ixodidae) in Thailand. Journal of medical entomology , 37 (4), 640. https://doi.org/10.1603/00222585-37.4.640

Lam, T. T., Jia, N., Zhang, Y. W., Shum, M. H., Jiang, J. F., Zhu, H. C., Tong, Y. G., Shi, Y. X., Ni, X. B., Liao, Y. S., Li, W. J., Jiang, B. G., Wei, W., Yuan, T. T., Zheng, K., Cui, X. M., Li, J., Pei, G. Q., Qiang, X., Cheung, W. Y., ... Cao, W. C. (2020). Identifying SARS-CoV-2-related coronaviruses in Malayan pangolins. Nature, Retrieved May 5, 2020, from https://doi.org/10.1038/s41586-020-2169-0

Li, F., Li, W., Farzan, M., \& Harrison, S.C. (2005). Structure of SARS coronavirus spike receptor-binding domain complexed with receptor. Science, 309 (5742): 1864-68. https://doi.org/10.1126/science.1116480

Loftis, A. D., Gill, J. S., Schriefer, M. E., Levin, M. L., Eremeeva, M. E., Gilchrist, M. J., \& Dasch, G. A. (2005). Detection of Rickettsia , Borrelia , and Bartonella inCarios kelleyi (Acari: Argasidae). Journal of medical entomology , 42 (3), 473-480. https://doi.org/10.1093/jmedent/42.3.473

Li, H.F., Lin, J.S., Lan, Y.C., Pei, K.J.C., \& Su, N.Y. (2011). Survey of the term Temminck's ground pangolin (Manis temminckii ) Rhinotermitidae, Termitidae in a Formosan pangolin habitat.Florida entomologist, 94 (3), 534-538. https://doi.org/10.1653/024.094.0318

Liu, P., Chen, W., \& Chen, J. P. (2019). Viral metagenomics revealed Sendai virus and coronavirus infection of Malayan Pangolins (Manis javanica ). Viruses , 11 (11), 979. https://doi.org/10.3390/v11110979 
Lu, R., Zhao, X., Li, J., Niu, P., Yang, B., Wu, H., .. Tan, W. (2020). Genomic characterisation and epidemiology of 2019 novel coronavirus: implications for virus origins and receptor binding.Lancet, 395 (10224), 565-574. https://doi. org/10.1016/S0140-6736(20)30251-8.

Málková, D., Holubová, J., Cerný, V., Daniel, M., Fernández, A., de la Cruz, J., Herrera, M., \& Calisher, C. H. (1985). Estero real virus: a new virus isolated from argasid ticks Ornithodoros tadaridae in Cuba. Acta virologica , 29 (3), 247-250. Retrieved May 29, 2020, from https://europepmc.org/article/med/2864827

Mediannikov, O., Davoust, B., Socolovschi, C., Tshilolo, L., Raoult, D., \& Parola, P. (2012). Spotted fever group rickettsiae in ticks and fleas from the Democratic Republic of the Congo. Ticks and Tick-borne Diseases, 3 (5-6), 371-373. https://doi.org/10.1016/j.ttbdis.2012.10.015.

Mohapatra, R.K., Panda, S., Nair, M.V., \& Acharjyo, L.N. (2016). Check list of parasites and bacteria recorded from pangolins (Manis sp.). Journal of parasitic diseases: official organ of the Indian Society for Parasitology , 40 (4), 1109-1115. https://doi.org/10.1007/s12639-015-0653-5

Nijhof, A.M., Penzhorn, B.L., Lynen, G., Mollel, J.O., Morkel, P., Bekker, C.P., \& Jongejan, F. (2003). Babesia bicornis sp. nov. and Theileria bicornis sp. nov.: tick-borne parasites associated with mortality in the black rhinoceros (Diceros bicornis ). Journal of clinical microbiology , 41 (5), 2249-2254. https://doi.org/10.1128/jcm.41.5.2249-2254.2003

Nuttall, P.A. (1984). Tick-borne viruses in seabird colonies.Seabird 7 , 31-41. Retrieved May 21, 2020, from http://www.seabirdgroup.org.uk/journals/seabird-7/seabird-7.pdf \#page=33

Nunn, M. A., Barton, T. R., Wanless, S., Hails, R. S., Harris, M. P., \& Nuttall, P. A. (2006). Tick-borne Great Island Virus: (I) Identification of seabird host and evidence for co-feeding and viraemic transmission. Parasitology , 132 (Pt 2), 233-240. https://doi.org/10.1017/S0031182005008930

Olival, K. J., Hosseini, P. R., Zambrana-Torrelio, C., Ross, N., Bogich, T. L., \& Daszak, P. (2017). Host and viral traits predict zoonotic spillover from mammals. Nature , 546 (7660), 646-650. https://doi.org/10.1038/nature22975

Parola, P., Paddock, C.D., Socolovschi, C., Labruna, M.B., Mediannikov, O., Kernif, T., ... Raoult, D. (2013). Update on tick-borne rickettsioses around the world: a geographic approach. Clinical microbiology reviews , 26 (4), 657-702. https://doi.org/10.1128/CMR.00032-13

Parola, P., Cornet, J. P., Sanogo, Y. O., Miller, R. S., Thien, H. V., Gonzalez, J. P., .. Wongsrichanalai, C. (2003). Detection ofEhrlichia spp., Anaplasma spp., Rickettsia spp., and other eubacteria in ticks from the Thai-Myanmar border and Vietnam. Journal of clinical microbiology , 41 (4), 1600-1608. https://doi.org/10.1128/jcm.41.4.1600-1608.2003

Pettersson, J.H.O., Ellström, P., Ling, J., Nilsson, I., Bergström, S., González-Acuña, D., .. Holmes, E.C. (2020). Circumpolar diversification of the Ixodes uriae tick virome. BioRxiv, Retrieved May 4, 2020, from https://doi.org/10.1101/2020.05.04.075515

Pulliam, J. R., \& Dushoff, J. (2009). Ability to replicate in the cytoplasm predicts zoonotic transmission of livestock viruses. The journal of infectious diseases , 199 (4), 565-568. https://doi.org/10.1086/596510

Ramos, J., Bowler, J., Laura Davis, Sarah Venis, Quinn, J., \& Carole Middleton (2001). Activity patterns and effect of ticks on growth and survival of tropical Roseate Tern nestlings. The Auk, 118 (3), 709-716. https://doi.org/10.2307/4089932

Robinson, P. (1983). The use of ketamine in restraint of a black-bellied Pangolin (Manis tetradactyla). The journal of zoo animal medicine, 14 (1), 19-23. https://doi.org/10.2307/20094623

Saikku, P., Main, A.J., Ulmanen, I., \& Brummer-Korvenkontio, M. (1980). Viruses in Ixodes uriae (Acari: Ixodidae) from seabird colonies at Røst Islands, Lofoten, Norway. Journal of medical entomology ,17 (4), 
360-366. https://doi.org/10.1093/jmedent/17.4.360

Sándor, A. D., Corduneanu, A., Péter, Á., Mihalca, A. D., Barti, L., Csôsz, I., .. Hornok, S. (2019). Bats and ticks: host selection and seasonality of bat-specialist ticks in eastern Europe. Parasites and vectors , 12 (1), 605. https://doi.org/10.1186/s13071-019-3861-5

Sanyal, A.K., De, S.K., Rao, A.T., Acharjyo, L.N. (1987). Metastigmata (Ticks), Fauna of Orissa.Zoological survey of India State Fauna series No. 1 , (pp 273-287). Retrieved May 30, 2020, from http://faunaofindia.nic.in/PDFVolumes/sfs/001/index.pdf

Socolovschi, C., Kernif, T., Raoult, D., \& Parola, P. (2012).Borrelia, Rickettsia, and Ehrlichia species in bat ticks, France, 2010. Emerging infectious diseases , 18 (12), 1966-1975. https://doi.org/10.3201/eid1812.111237

Traavik, T. (1977). Development of a modified immunoelectroosmophoresis method for Uukuniemi and Runde Virus serology. Archives of virology 54, 231-240. Retrieved May 3, 2020, from https://link.springer.com/article/10.1007/BF01314789

Traavik T. (1978). Experimental "Runde" virus infections in embryonated eggs and chickens. Acta pathologica et microbiologica scandinavica. section B, microbiology , 86B (5), 299-301. https://doi.org/10.1111/j.16990463.1978.tb00047.x

Traavik T. (1978). Persistent infections with "runde" virus in cell cultures and suckling mice. Acta pathologica et microbiologica scandinavica. section B, microbiology , 86B (6), 355-359. https://doi.org/10.1111/j.16990463.1978.tb00056.x

Traavik T. (1979). The influence of specific antisera and unheated guinea pig serum on the pathogenicity of "Runde" virus for mice. Acta pathologica et microbiologica scandinavica. section B, microbiology , 87B (1), 1-8. https://doi.org/10.1111/j.1699-0463.1979.tb02395.x

Traavik, T. \& Mehl, R. (1975). Tick-borne Viruses in Norway.Medical Biology 53 (5), 621-624. Retrieved May 3, 2020, from https://europepmc.org/article/med/1207194

Traavik, T., Mehl, R., \& Kjeldsberg, E. (1977). "Runde" viurs, a coronavirus-like agent associated with seabirds and ticks. Archives of virology , 55 (1-2), 25-38. https://doi.org/10.1007/BF01314476

Traavik, T., \& Brunvold, E. (1978). "Runde" virus: further characteristics and a method for purification. Acta pathologica et microbiologica scandinavica. section B, microbiology , 86B (6), 349-353. https://doi.org/10.1111/j.1699-0463.1978.tb00055.x

VIsME (Free version) [Graphic design software]. Retrieved June 2, 2020, from https://www.visme.co/

Wang, M., Yan, M., Xu, H., Liang, W., Kan, B., Zheng, B., .. X Xu, J. (2005). SARS$\mathrm{CoV}$ infection in a restaurant from Palm civet. Emerging infectious diseases , 11 (12), 1860-1865. https://doi.org/10.3201/eid1112.041293

Wang, W., Lin, X.D., Liao, Y., Guan, X.Q., Guo, W.P., Xing, J.G., .. Zhang, Y.Z. (2017). Discovery of a Highly Divergent Coronavirus in the Asian House Shrew from China Illuminates the origin of the Alphacoronaviruses. Journal of virology , 91 (17), e00764-17. https://doi.org/10.1128/JVI.00764-17

Wang, Z.D., Wang, B., Wei, F., Han, S.Z., Zhang, L., Yang, Z.T., .. Liu, Q. (2019). A new segmented virus associated with human febrile illness in China. The New England journal of medicine , 380 (22), 2116-2125. https://doi.org/10.1056/NEJMoa1805068

World Health Organization (WHO), (2020a). Statement on the second meeting of the International Health Regulations (2005) Emergency Committee regarding the outbreak of novel coronavirus (2019-nCoV). World Health Organization (WHO), Retrieved May 30, 2020, from https://www.who.int/news-room/detail/30-012020-statement-on-the-second-meeting-of-the-international-health-regulations-(2005)-emergency-committeeregarding-the-outbreak-of-novel-coronavirus-(2019-ncov) 
World Health Organization (WHO), (2020b). Director-General's opening remarks at the media briefing on COVID-19-11 March 2020. World Health Organization (WHO) , Retrieved May 30, 2020, from https://www.who.int/dg/speeches/detail/who-director-general-s-opening-remarks-at-the-mediabriefing-on-covid-19-11-march-2020

World Health Organization (WHO), (2020c). Novel Coronavirus-China. World Health Organization (WHO) . Retrieved May 9, 2020, from https://www.who.int/csr/don/12-january-2020-novel-coronavirus-china/en/

World Health Organization (WHO), (2020d). Naming the coronavirus disease (COVID-19) and the virus that causes it. World Health Organization (WHO), Retrieved May 2, 2020, from https://www.who.int/emergencies/diseases/novel-coronavirus-2019/technical-guidance/naming-thecoronavirus-disease-(covid-2019)-and-the-virus-that-causes-it

Zahn, A., \& Rupp, D. (2004). Ectoparasite load in European vespertilionid bats. Journal of zoology, 262 (4), 383-391. https://doi.org/10.1017/S0952836903004722

Zhou, P., Yang, X.L., Wang, X.G., Hu, B., Zhang, L., Zhang, W., ... Shi, Z.L. (2020). A pneumonia outbreak associated with a new coronavirus of probable bat origin. Nature , 579 (7798), 270-273. https://doi.org/10.1038/s41586-020-2012-7

Zingg, W., Castro-Sanchez, E., Secci, F.V., Edwards, R., Drumright, L.N., Sevdalis, N., \& Holmes, A.H. (2016). Innovative tools for quality assessment: integrated quality criteria for review of multiple study designs (ICROMS). Public health , 133 , 19-37. https://doi.org/10.1016/j.puhe.2015.10.012

\section{FIGURE LEGENDS}

FIGURE 1 Evidence captured within a systematic review (from year 1973 to year 2020) to provide hints and more hypotheses on the origin of tick's coronavirus and the possibilities of ticks transmitting coronavirus.

FIGURE 2 Possible geographical distribution of hard ticks linked with pangolins. Note: geographical distribution of some of the ticks linked with pangolins was unidentified. Map created with VIsME software.

FIGURE 3 Possible geographic distribution of hard ticks linked with seabirds. Map created with VIsME software.

FIGURE 4 Possible geographic distribution of hard ticks linked with bats. Map created with VIsME software.

FIGURE 5 Hypothesis about the possible ways that $I$. uriae ticks can use to transmit SARS-CoV-2 to humans. 


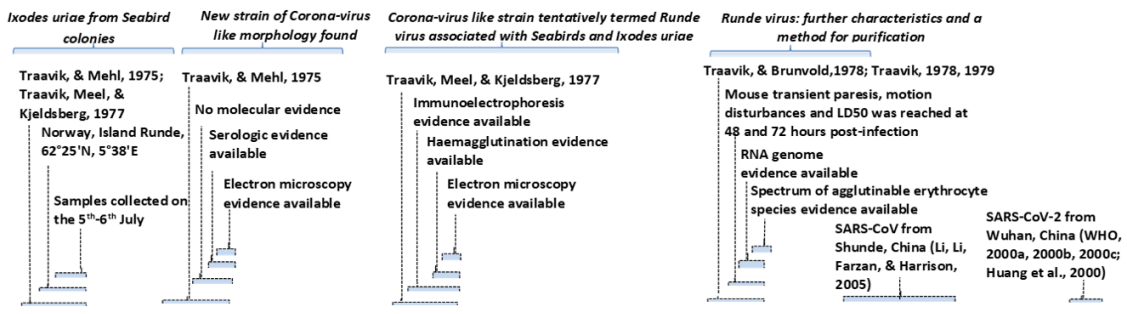

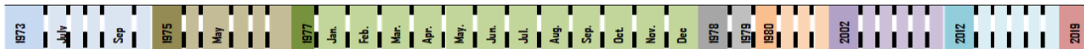

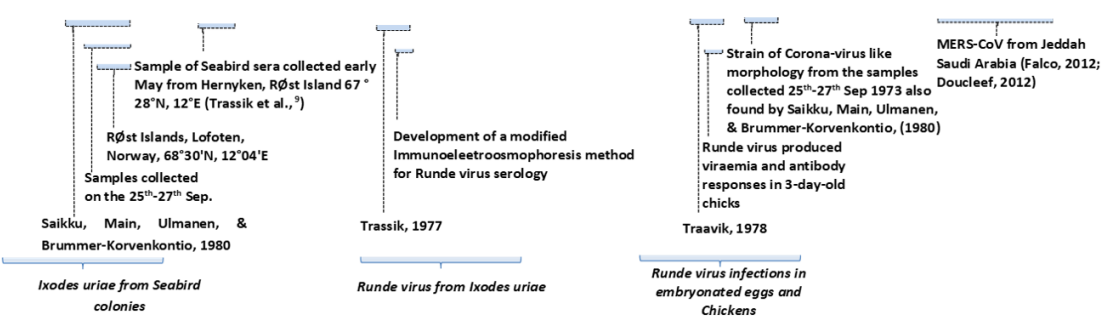




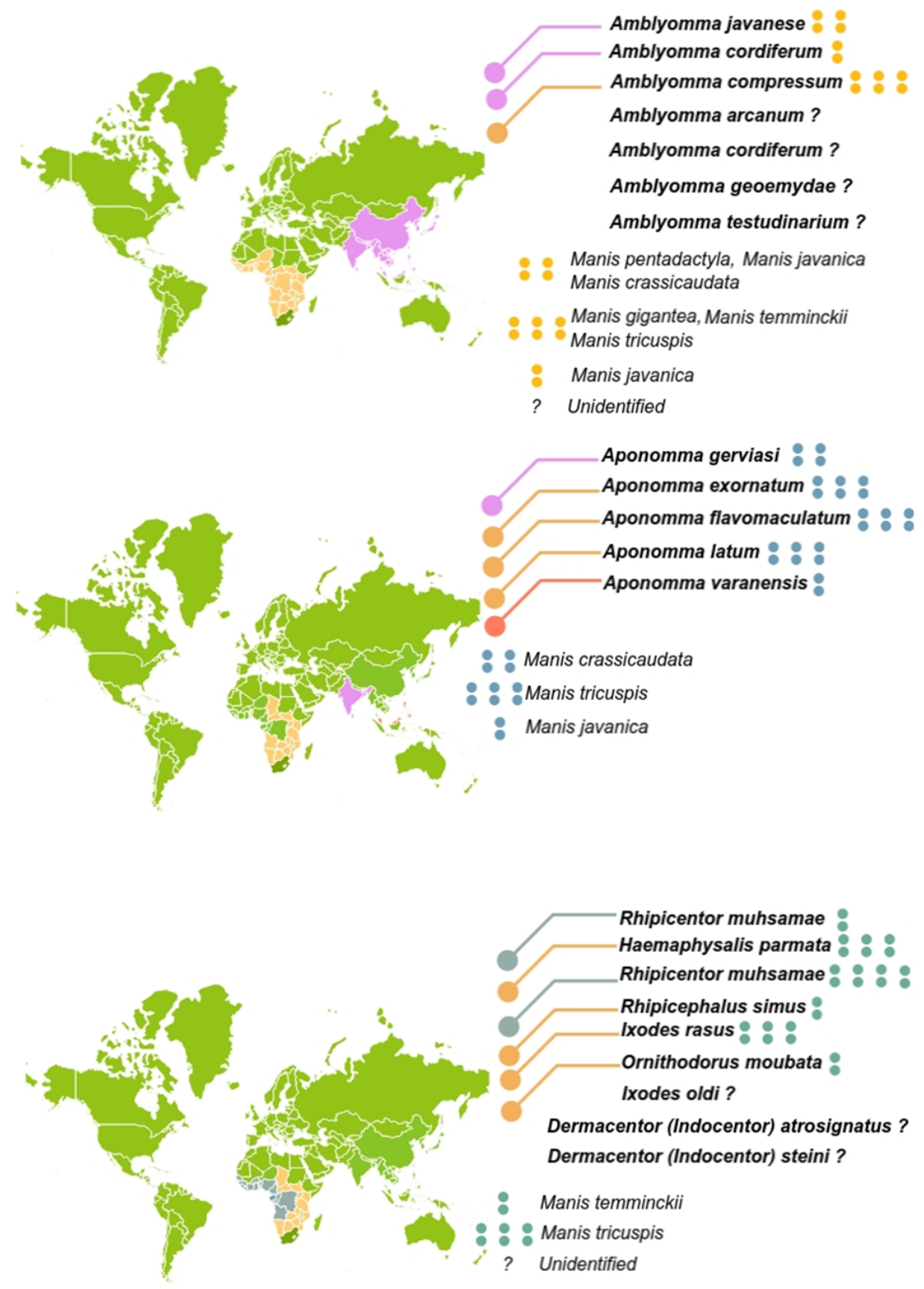



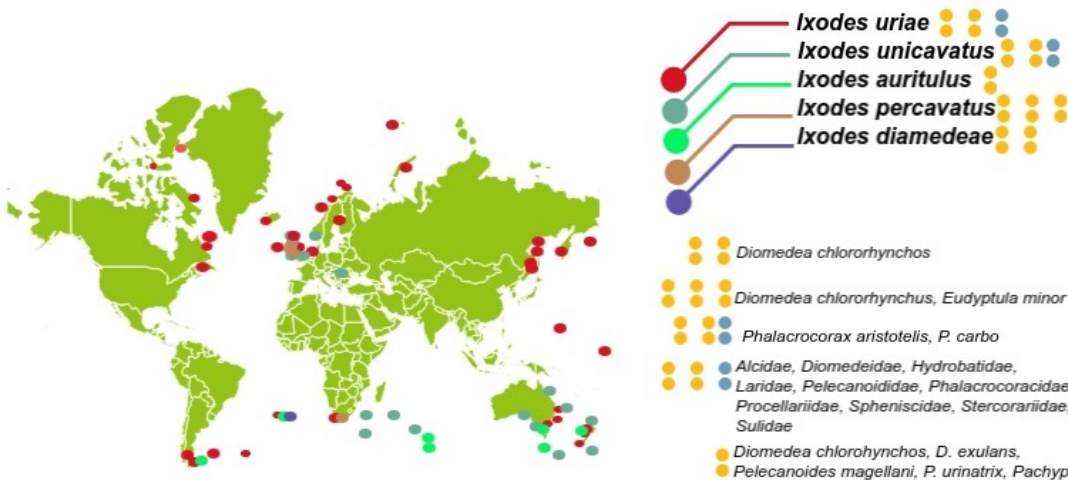

: Diomedea chlororhynchos

: : Diomedea chlororhynchus, Eudyptula minor

$\because: 8$ Phalacrocorax aristotelis, P. carbo

: Alcidae, Diomedeidae, Hydrobatidae, Laridae, Pelecanoididae, Phalacrocoracidae,
Procellaridae, Spheniscidae, Stercorariidae,

- Diomedea chlorohynchos, D. exulans,

Pelecanoides magellani, $P$, urinatrix, Pachyptila griseus, P. travis, Aptenodytes patagonica,

Catharacta lonnbergi

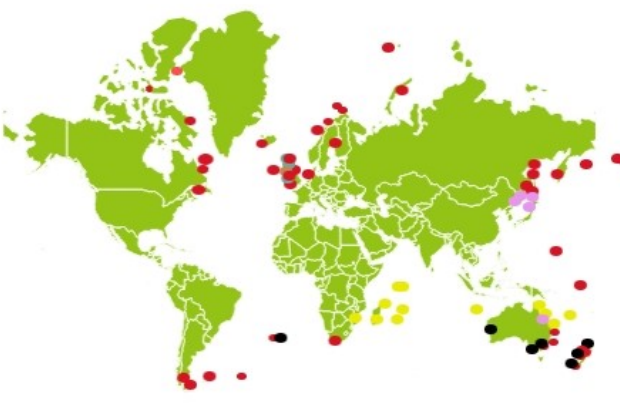

Ixodes amersoni
Amblyomma loculosum
Ixodes rothschildi:
Ixodes philip
Ixodes murreleti
Ixodes kerguelenensis:

Diomedea exulans, D. chlororhynchus,

Diomedea exusa,
Phoebetria fusca, Pterodorma brevirostris, . P. mollis, Pachyptila desolata, Puffinus

政, georgicus

$:: 8$ Synthiliboramphus hypoleucus

$: 8:$ Oceanodroma castro, Calonectris leucomelas

$\because:$ Alca torda, Fratercula arctica, Larus aristotelis, Fulmarus puffinus

6 Fregata ariel, F. minor, Anous stolidus, A. - minutus, Phaethon lepturus, Puffinus pacificus,
P. putfinus, Stema fuscata, S. dougalli, Sula P. putfinus, Stema fuscata, S. dougalli, Sul sula, S. leucogaster, S. dactylatra

- Diomedea nigripes, Fregata minor, Gygis alba, Anous stolidus, Sula sula

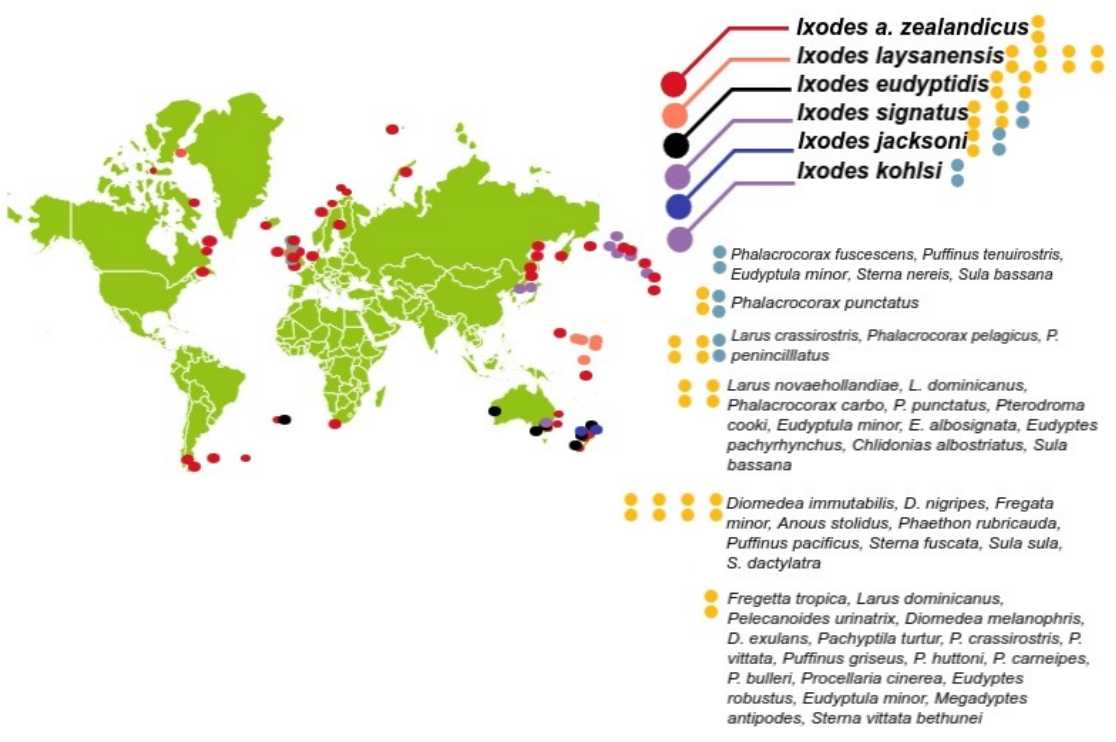



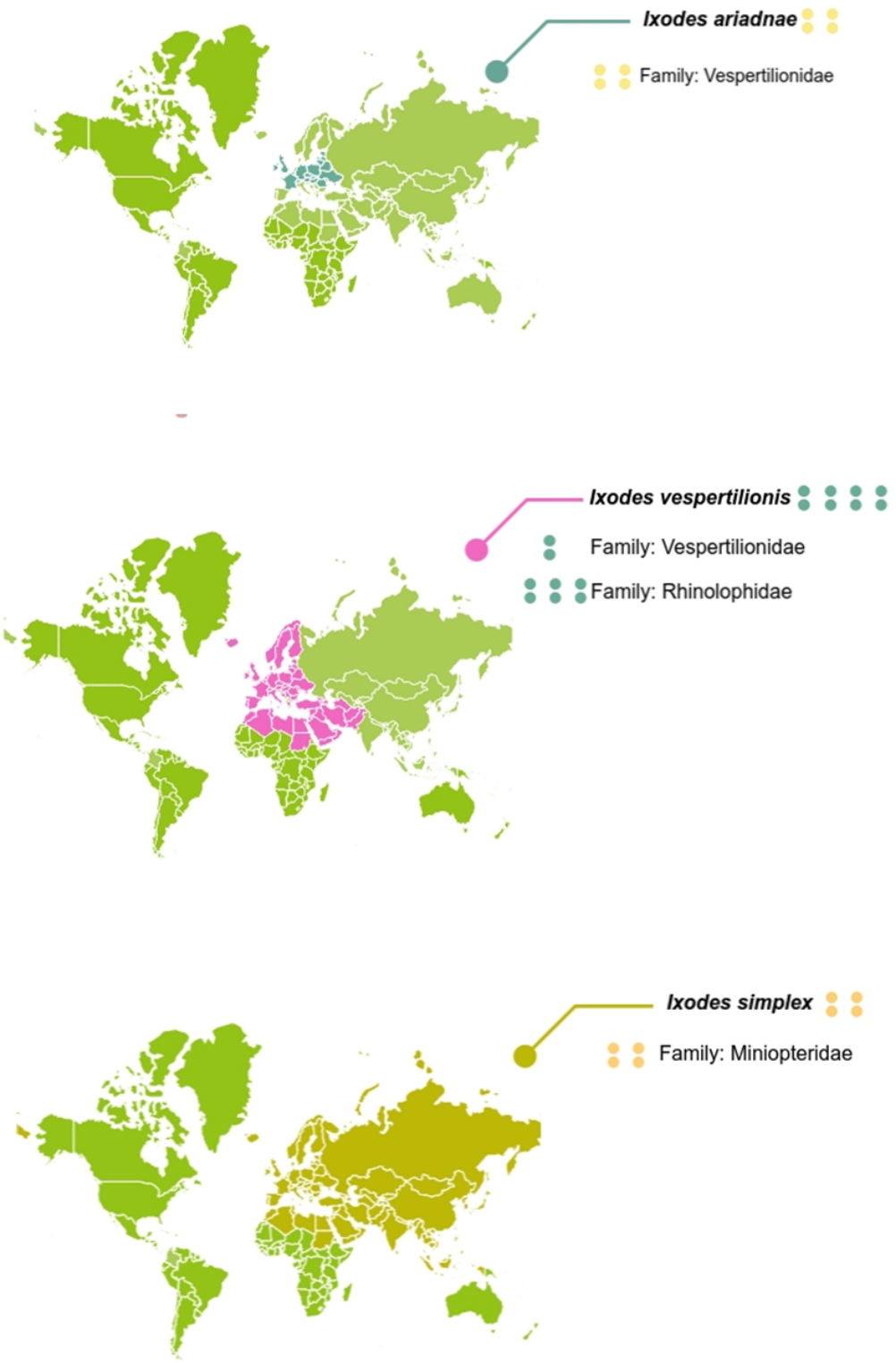

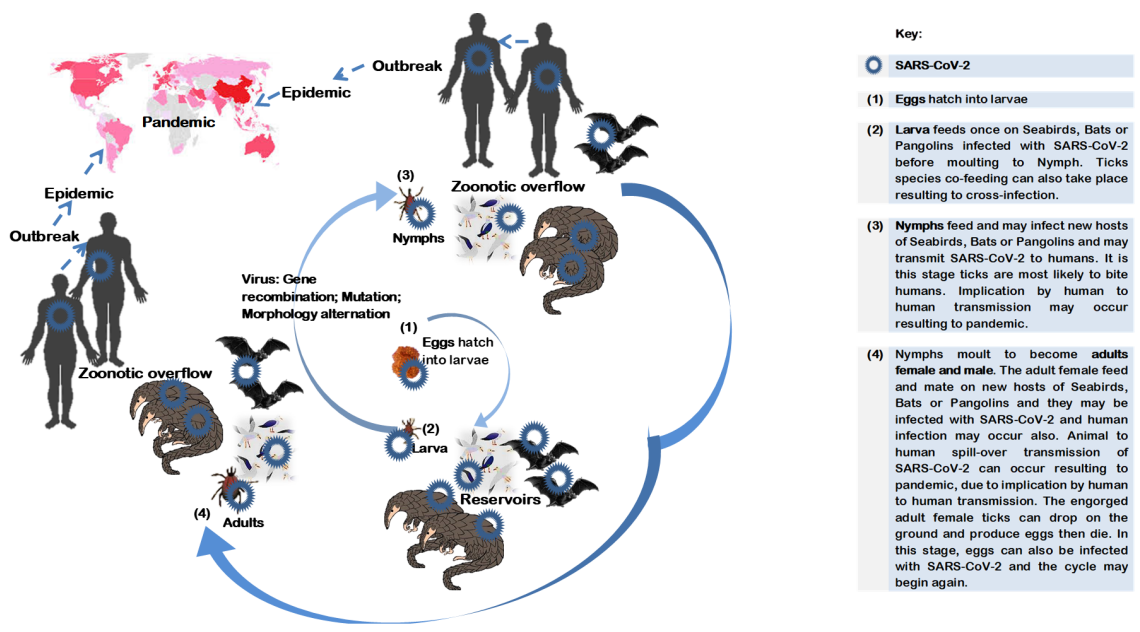